Article

\title{
Design, Synthesis and In Vitro Characterization of Novel Antimicrobial Agents Based on 6-Chloro-9H-carbazol Derivatives and 1,3,4-Oxadiazole Scaffolds
}

\author{
Alexandra T. Bordei Telehoiu ${ }^{1}$, Diana C. Nuță ${ }^{1} \mathbb{C}$, Miron T. Căproiu ${ }^{2, *}$, Florea Dumitrascu ${ }^{2, *}$, \\ Irina Zarafu ${ }^{3}\left(\mathbb{D}\right.$, Petre Ioniță ${ }^{3}\left(\mathbb{D}\right.$, Carmellina D. Bădiceanu ${ }^{1}$, Speranța Avram ${ }^{4}$, \\ Mariana C. Chifiriuc ${ }^{5}$, Coralia Bleotu ${ }^{6}(\mathbb{D})$ and Carmen Limban ${ }^{1}$ (D) \\ 1 Department of Pharmaceutical Chemistry, Faculty of Pharmacy, "Carol Davila” University of Medicine and \\ Pharmacy, 6 TraianVuia, 020956 Bucharest, Romania; alexandratelehoiu@yahoo.com (A.T.B.T.); \\ diananuta@yahoo.com (D.C.N.); bcarmellina@yahoo.com (C.D.B.); carmen_limban@yahoo.com (C.L.) \\ 2 Center for Organic Chemistry "C.D. Nenitzescu”, Romanian Academy, 202B Spl. Independentei, \\ 060023 Bucharest, Romania \\ 3 Department of Organic Chemistry, Biochemistry and Catalysis, Faculty of Chemistry, University of Bucharest, \\ 4-12 Regina Elisabeta, 030018 Bucharest, Romania; zarafuirina@yahoo.fr (I.Z.); p_ionita@yahoo.co.uk (P.I.) \\ 4 Department of Anatomy, Animal Physiology and Biophysics, Faculty of Biology, University of Bucharest, 1-3 \\ Ale. Portocalelor, 060101 Bucharest, Romania; speranta.avram@gmail.com \\ 5 Research Institute of the University of Bucharest (ICUB) and Microbiology Immunology Department, \\ Faculty of Biology, University of Bucharest, 1-3 Ale. Portocalelor, 060101 Bucharest, Romania; \\ carmen.chifiriuc@bio.unibuc.com \\ 6 Ștefan S. Nicolau Institute of Virology, Romanian Academy, 285 Mihai Bravu Avenue, 030304 Bucharest, \\ Romania; cbleotu@yahoo.com \\ * Correspondence: dorucaproiu@gmail.com (M.T.C.); fdumitra@yahoo.com (F.D.); \\ Tel.: +40-213167900 (M.T.C. \& F.D.); Fax: +40-213121601 (M.T.C. \& F.D.)
}

Received: 19 November 2019; Accepted: 8 January 2020; Published: 9 January 2020

check for updates

\begin{abstract}
In this paper, we aimed to exploit and combine in the same molecule the carbazole and the 1,3,4-oxadiazole pharmacophores, to obtain novel carprofen derivatives, by using two synthesis pathways. For the first route, the following steps have been followed: (i) (RS)-2-(6-chloro-9H-carbazol-2-yl)propanonic acid (carprofen) treatment with methanol, yielding methyl (RS)-2-(6-chloro-9H-carbazol-2-yl)propanoate; (ii) the resulted methylic ester was converted to $(R S)$-2-(6-chloro-9H-carbazol-2-yl)propane hydrazide (carprofen hydrazide) by treatment with hydrazine hydrate; (iii) reaction of the hydrazide derivative with acyl chlorides led to $N$-[(2RS)-2-(6-chloro-9H-carbazol-2-yl)propanoil]- $N^{\prime}-R$-substituted-benzoylhydrazine formation, which; (iv) in reaction with phosphorus oxychloride gave the (RS)-1-(6-chloro-9H -carbazol-2-yl)-1-(1,3,4-oxadiazol-2-yl)ethane derivatives. In the second synthesis pathway, new 1,3,4-oxadiazole ring compounds were obtained starting from carprofen which was reacted with isoniazid, in the presence of phosphorus oxychloride to form (RS)-1-(6-chloro-9H -carbazol-2-yl)-1-[5-(4-pyridyl)-1,3,4-oxadiazol-2-yl]ethane. The synthesized compounds were characterized by IR, ${ }^{1} \mathrm{H}-\mathrm{NMR}$ and ${ }^{13} \mathrm{C}-\mathrm{NMR}$, screened for their drug-like properties and evaluated for in vitro cytotoxicity and antimicrobial activity. The obtained compounds exhibited a good antimicrobial activity, some of the compounds being particularly active on $E$. coli, while others on $C$. albicans. The most significant result is represented by their exceptional anti-biofilm activity, particularly against the P. aeruginosa biofilm. The cytotoxicity assay revealed that at concentrations lower than 100 $\mu \mathrm{g} / \mathrm{mL}$, the tested compounds do not induce cytotoxicity and do not alter the mammalian cell cycle. The new synthesized compounds show good drug-like properties. The ADME-Tox profiles indicate a good oral absorption and average permeability through the blood brain barrier. However, further research is needed to reduce the predicted mutagenic potential and the hepatotoxicity.
\end{abstract}


Keywords: oxadiazole; carbazole; carprofen; antimicrobial; cytotoxicity; in silico

\section{Introduction}

Carbazole and its derivatives represent an important group of aromatic heterocyclic compounds containing a nitrogen atom. Compounds containing this scaffold have important electronic and charge-transport properties, as well as a conjugated pi-electron system, which facilitate the easy introduction of various functional groups into the structurally rigid carbazole ring [1].

These properties result in the extensive applications of carbazole derivatives in the medical field, such as antitumor, antimicrobial, antihistaminic, antioxidant, anti-inflammatory, and psychotropic agents [2].

The carbazole nucleus can be naturally found in the composition of some alkaloids as ellipticine [3], with antimalarial properties and koenidine, with potential antidiabetic effect [4], or staurosporine, with antibacterial, antifungal, and antitumoral activity [5], among them carbazomycins represent an unprecedented class of antibiotics with a carbazole heterocycle [6]. Carbazomycins A and B have proven to have antibacterial and antifungal activity, inhibiting the growth of phytopathogenic fungi, while Murrayafolin A, a compound isolated from Murraya euchrestifolia Hayata has shown a strong fungicidal effect on Cladosporium cucumerinum [7]. A new carbazole-derived alkaloid (1,8-dimethoxy-3-formylcarbazole) was isolated from the leaves of Clausena heptaphylla, being active against Gram-positive and Gram-negative bacteria, as well as fungi [8]. The carbazole acid ring is also present in many drugs, such as olivacine (antimalarial), rimcazole (antipsychotic and anticonvulsant), carvedilol (antihypertensive) [1,2] (Figure 1).

Some members of carbazole series have been shown to exhibit a broad spectrum of antifungal activity, acting as potent fungal plasma membrane proton adenosine triphosphatase inhibitors [9]. For example, 9-(9-ethyl-9H-carbazol-3-yl)-2-(phenoxy)acetamide derivatives, obtained by reacting 2-chloro- $\mathrm{N}$-(9-ethyl-9H-carbazol-3-yl)acetamide with substituted phenols have shown antimicrobial activity [10]. Novel 5-[(9H-carbazol-9-yl)methyl]- $N-[($ substituted phenyl)(piperazin-1-yl)methyl]-1,3,4-oxadiazol-2-amines derivatives proved an antimicrobial effect and anti-proliferative activity, against the breast cancer cell line MCF7 [11].

Carprofen (2-(6-chloro-9H-carbazol-2-yl)propanoic acid) is a non-steroidal anti-inflammatory drug (NSAID), included in the class of propionic acid derivatives, that inhibits both COX-1 and COX-2 and is used commonly to combat inflammation and pain in animals with osteoarthritis or other inflammatory diseases. Carprofen was previously used in human medicine for over 10 years (1985-1995). It was generally well tolerated, with only mild side effects, such as gastro-intestinal pain and nausea. It is no longer marketed for human usage, after being withdrawn on commercial grounds, but is used by veterinarians as a supportive treatment for the relief of arthritic symptoms in geriatric dogs.

1,3,4-Oxadiazoles are heterocyclic compounds which have a diversity of useful biological effects including antibacterial [12], antifungal [13], analgesic [14], anti-inflammatory [15], antiviral [16], anticancer [17], antihypertensive [18], anticonvulsant [19], and anti-diabetic [20] properties.

1,3,4-Oxadiazole nucleus is contained in the molecules of drugs such as: Furamizole (antibacterial), tiodazosin (an alpha-1 adrenergic antagonist), nesapidil (antihypertensive), raltegravir (antiretroviral), and zibotentan (anticancer) (Figure 2) [21]. 
<smiles>Cc1c2ccncc2c(C)c2c1[nH]c1ccccc12</smiles>

Ellipticine

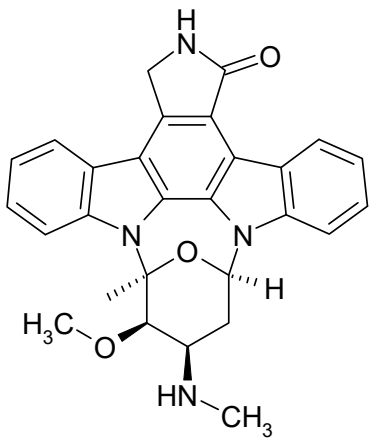

Staurosporine<smiles>COc1cc2[nH]c3c4c(c(C)cc3c2cc1OC)OC(C)(C)C=C4</smiles>

Koenidine<smiles>Cc1nccc2c(C)c3[nH]c4ccccc4c3cc12</smiles>

Olivacine<smiles>[R]Oc1c(OC)c(C)c(C)c2[nH]c3ccccc3c12</smiles><smiles>COc1cc(OC)c2[nH]c3ccccc3c2c1</smiles>

Murrayafolin A

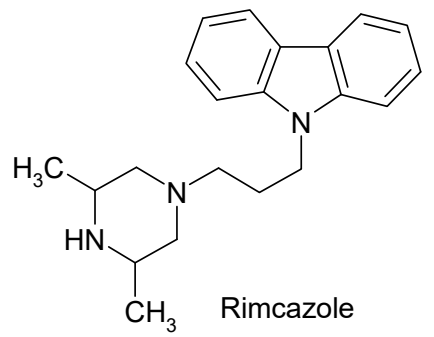<smiles>COc1ccccc1OCCNCC(O)COc1cccc2[nH]c3ccccc3c12</smiles>

Figure 1. Carbazole derivatives with pharmacological properties.<smiles>Nc1nnc(C(=Cc2ccc([N+](=O)[O-])o2)c2ccco2)o1</smiles>

Furamizole<smiles>COc1cc2nc(N3CCN(C(=O)c4nnc(SC)o4)CC3)nc(N)c2cc1OC</smiles><smiles>[R10][R11]([H])([H])c1nc(C(=O)NCc2ccc(F)cc2)c(O)c(=O)n1C</smiles><smiles>COc1nc(C)cnc1NS(=O)(=O)c1cccnc1-c1ccc(-c2nnco2)cc1</smiles>

Zibotentan

Figure 2. 1,3,4-Oxadiazole derivatives used as drugs. 
The most commonly used synthetic route for the synthesis of 1,3,4-oxadiazoles includes the reactions of acid hydrazides with acid chlorides or carboxylic acids and cyclization of the formed acylhydrazines using a dehydrating agent, such as phosphorous pentaoxide, thionyl chloride, or phosphorous oxychloride [22].

In the present study, we aimed to combine in the same molecular framework the carbazole and the 1,3,4-oxadiazole pharmacophores, to obtain novel carprofen derivatives. The new synthesized compounds were characterized by IR, ${ }^{1} \mathrm{H}-\mathrm{NMR}$ and ${ }^{13} \mathrm{C}-\mathrm{NMR}$, screened for their drug-like properties and evaluated for in vitro cytotoxicity and antimicrobial activity.

\section{Results}

\subsection{Chemistry}

The synthesis routes approached to obtain the target compounds are outlined in Scheme 1.
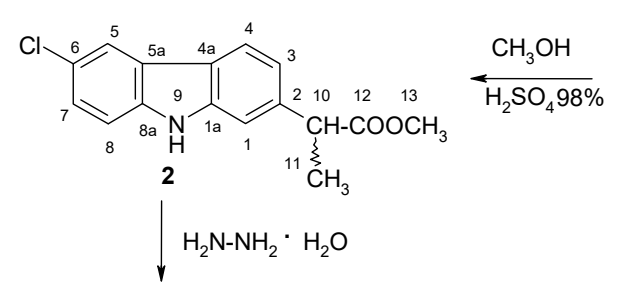<smiles>C[C@H](C(=O)O)c1ccc2c(c1)[nH]c1ccc(Cl)cc12</smiles><smiles>C[C@H](C(=O)NN)c1ccc2c(c1)[nH]c1ccc(Cl)cc12</smiles><smiles>NNC(=O)c1ccncc1</smiles><smiles>[R]c1ccc(C(=O)Cl)cc1</smiles><smiles>[R][R]([H])([H])[O-]</smiles><smiles>[R][X]1([H])cccc(-c2nnc([C@H](C)c3ccc4c(c3)[nH]c3ccc(Cl)cc34)o2)c1</smiles>

5a-c $\mathrm{R}=-\mathrm{H}, 4-\mathrm{Cl}, 3-\mathrm{CF}_{3}$

Scheme 1. Synthesis pathways for the novel 2,5-disubstituted 1,3,4-oxadiazole 5a-d.

The reaction of (RS)-2-(6-chloro-9H-carbazol-2-yl)propanoic acid (carprofen) (1) with methanol, in the presence of concentrated sulfuric acid leading to methyl (2RS)-2-(6-chloro-9H -carbazol-2-yl)propanoate (carprofen methyl ester) (2). The reaction of compound 2 with hydrazine hydrate in refluxing ethanol gave (2RS)-2-(6-chloro-9H-carbazol-2-yl)propane hydrazide (carprofen hydrazide) (3). 
The $N, N^{\prime}$-disubstituted hydrazines (4a-c) were obtained by stirring the carprofen hydrazide (3) and the acyl chloride at room temperature in anhydrous pyridine.

The IR spectrum of compounds $4 \mathbf{a}-\mathbf{c}$ showed characteristic absorption band at $3201-3215 \mathrm{~cm}^{-1}$ due to N-H group and also to carbonyl absorption bands at $1706-1702$ and $1649-1651 \mathrm{~cm}^{-1}$. Its ${ }^{1} \mathrm{H}-\mathrm{NMR}$ spectrum revealed singlets at $\delta 10.15-10.19$ and $10.34-10.66 \mathrm{ppm}$ due to two NH protons of the hydrazide moiety, in addition to singlet at $\delta 11.38-11.41 \mathrm{ppm}$ assignable for $-\mathrm{NH}$ - proton of the carbazole core. The ${ }^{13} \mathrm{C}-\mathrm{NMR}$ spectral data for compounds $4 \mathrm{a}-\mathrm{c}$ revealed signals in the aromatic region and additional two singlets around $\delta 172.74-172.90$ and in the region $164-165.93 \mathrm{ppm}$ for the two carbonyl groups, which are in agreement with the assigned structures.

For the synthesis of 2,5-disubstituted 1,3,4-oxadiazoles (5a-c) the corresponding acylhydrazide was heated on the water bath with phosphorus oxychloride.

Starting from carprofen we also obtained (RS)-1-(6-chloro-9H-carbazol-2-yl)-1-[5-(4-pyridyl)-1,3,4 -oxadiazol-2-yl]ethane (5d) by reaction with isoniazid, in the presence of phosphorus oxychloride.

The IR spectrum of compounds 5a-d showed absorption bands in the region $3238-3268 \mathrm{~cm}^{-1}$ due to $\mathrm{NH}$ group. Its ${ }^{1} \mathrm{H}-\mathrm{NMR}$ spectrum displayed a doublet band at $\delta 1.80-1.90 \mathrm{ppm}$ and quartet at 4.58-4.80 ppm corresponding to $-\mathrm{CH}_{3}$ and $-\mathrm{CH}$ - groups, respectively. The presence of the ethanyl group was also confirmed by signals around $\delta 19.50-20.04$ and 36.98-38.01 ppm in the ${ }^{13} \mathrm{C}-\mathrm{NMR}$ spectrum of these compounds, which correspond to $-\mathrm{CH}_{3}$ and $-\mathrm{CH}$ - groups, respectively.

\subsection{Biological Assays}

The tested compounds presented MIC values ranging from 0.625 to $10 \mathrm{mg} / \mathrm{mL}$ (Table 1). The most susceptible microbial strains were the Gram-negative bacteria, followed by the fungal C. albicans strain. The best antibacterial effect was recorded for $4 \mathbf{a}$ against $E$. coli, with MIC of $1.25 \mathrm{mg} / \mathrm{mL}$ and for $5 \mathbf{c}$ against C. albicans, with MIC of $0.625 \mathrm{mg} / \mathrm{mL}$.

Table 1. MIC (mg/mL) values for the compounds $4 \mathbf{a}-\mathbf{c}$, 5a-d.

\begin{tabular}{cccccccc}
\hline Compound & $\mathbf{4 a}$ & $\mathbf{4 b}$ & $\mathbf{4 c}$ & $\mathbf{5 a}$ & $\mathbf{5 b}$ & $\mathbf{5 c}$ & $\mathbf{5 d}$ \\
\hline $\begin{array}{c}\text { Microorganism } \\
\text { ATCrococcus faecalis }\end{array}$ & 10 & 5 & 10 & 5 & 5 & 2.5 & 5 \\
\hline $\begin{array}{c}\text { Staphylococcus aureus } \\
\text { ATCC 25923 }\end{array}$ & 5 & 5 & 2.5 & 2.5 & 5 & 5 & 5 \\
\hline $\begin{array}{c}\text { Pseudomonas aeruginosa } \\
\text { ATCC 27853 }\end{array}$ & 2.5 & 2.5 & 2.5 & 2.5 & 2.5 & 2.5 & 2.5 \\
\hline $\begin{array}{c}\text { Escherichia coli } \\
\text { ATCC 25922 }\end{array}$ & 1.25 & 2.5 & 2.5 & 2.5 & 2.5 & 5 & 2.5 \\
\hline $\begin{array}{c}\text { Candida albicans } \\
\text { ATCC 90029 }\end{array}$ & 5 & 2.5 & 5 & 2.5 & 2.5 & 0.625 & 5 \\
\hline
\end{tabular}

The minimal bactericidal concentration (MBC) values ranged in the same interval as the MIC ones, being equal or one time higher than that corresponding MIC values, suggesting a microbicidal mechanism of action (Table 2). 
Table 2. Minimal bactericidal concentration $(\mathrm{MBC})(\mathrm{mg} / \mathrm{mL})$ values for the compounds $\mathbf{4 a -} \mathbf{-}, \mathbf{5 a}-\mathbf{d}$.

\begin{tabular}{|c|c|c|c|c|c|c|c|}
\hline Microorganism & $4 a$ & $4 b$ & $4 c$ & $5 a$ & $5 b$ & $5 c$ & $5 d$ \\
\hline $\begin{array}{c}\text { Enterococcus faecalis } \\
\text { ATCC } 29212\end{array}$ & 10 & 10 & 10 & 10 & 10 & 5 & 5 \\
\hline $\begin{array}{c}\text { Staphylococcus aureus } \\
\text { ATCC } 25923\end{array}$ & 5 & 5 & 5 & 5 & 5 & 5 & 5 \\
\hline $\begin{array}{c}\text { Pseudomonas aeruginosa } \\
\text { ATCC } 27853\end{array}$ & 2.5 & 2.5 & 2.5 & 2.5 & 2.5 & 2.5 & 2.5 \\
\hline $\begin{array}{l}\text { Escherichia coli } \\
\text { ATCC } 25922\end{array}$ & 1.25 & 5 & 5 & 5 & 5 & 5 & 5 \\
\hline $\begin{array}{l}\text { Candida albicans } \\
\text { ATCC } 90029\end{array}$ & 10 & 5 & 10 & 5 & 5 & 0.625 & 10 \\
\hline
\end{tabular}

All tested compounds exhibited excellent anti-biofilm properties against the bacterial and fungal strains, with Minimal Biofilm Eradication Concentration (MBEC) values generally ranging from 0.009 to $2.5 \mathrm{mg} / \mathrm{mL}$ (Table 3). The MBEC values were in some cases up to 256 times lower than MIC or MBC (Table 3). The highest susceptibility to all tested compounds was recorded for the P. aeruginosa biofilm.

Table 3. MBEC (mg/mL) values for the compounds $4 \mathbf{a}-\mathbf{c}, \mathbf{5 a}-\mathbf{d}$.

\begin{tabular}{|c|c|c|c|c|c|c|c|}
\hline Microorganism & $4 a$ & $4 b$ & $4 c$ & $5 a$ & $5 b$ & $5 c$ & $5 d$ \\
\hline $\begin{array}{l}\text { Enterococcus faecalis } \\
\text { ATCC } 29212\end{array}$ & 2.5 & 0.009 & 2.5 & 1.25 & 0.078 & 10 & 0.625 \\
\hline $\begin{array}{c}\text { Staphylococcus aureus } \\
\text { ATCC } 25923\end{array}$ & 1.25 & 0.625 & 1.25 & 0.312 & 0.039 & 1.25 & 0.312 \\
\hline $\begin{array}{c}\text { Pseudomonas aeruginosa } \\
\text { ATCC } 27853\end{array}$ & 0.009 & 0.009 & 0.009 & 0.009 & 0.009 & 0.009 & 0.625 \\
\hline $\begin{array}{l}\text { Escherichia coli } \\
\text { ATCC } 25922\end{array}$ & 1.25 & 1.25 & 1.25 & 10 & 1.25 & 2.5 & 1.25 \\
\hline $\begin{array}{l}\text { Candida albicans } \\
\text { ATCC } 90029\end{array}$ & 0.312 & 0.039 & 0.625 & 0.078 & 1.25 & 0.312 & 0.156 \\
\hline
\end{tabular}


For the in vitro cytotoxicity assay, the results show that the tested compounds become toxic at concentrations higher than $100 \mu \mathrm{g} / \mathrm{mL}$, with the HeLa cells and HaCaT cells viability gradually decreasing after $48 \mathrm{~h}$ of incubation, in a dose-dependent manner (Figure 3). All tested compounds are highly toxic at $1 \mathrm{mg} / \mathrm{mL}$, the cellular viability decreasing dramatically after $24 \mathrm{~h}$ of incubation (Figure 4).
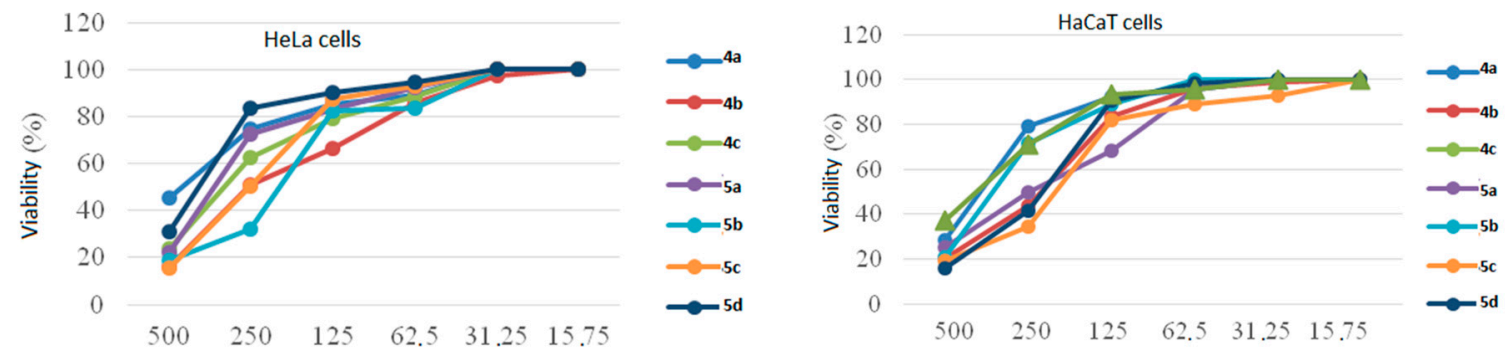

Figure 3. The cytotoxicity of compounds $\mathbf{4 a}-\mathbf{c}, \mathbf{5 a}-\mathbf{d}$ on HeLa and HaCaT cells (evaluation at $48 \mathrm{~h}$, using CellTiter $96^{\circledR} \mathrm{AQ}$ ueous One Solution Cell Proliferation).
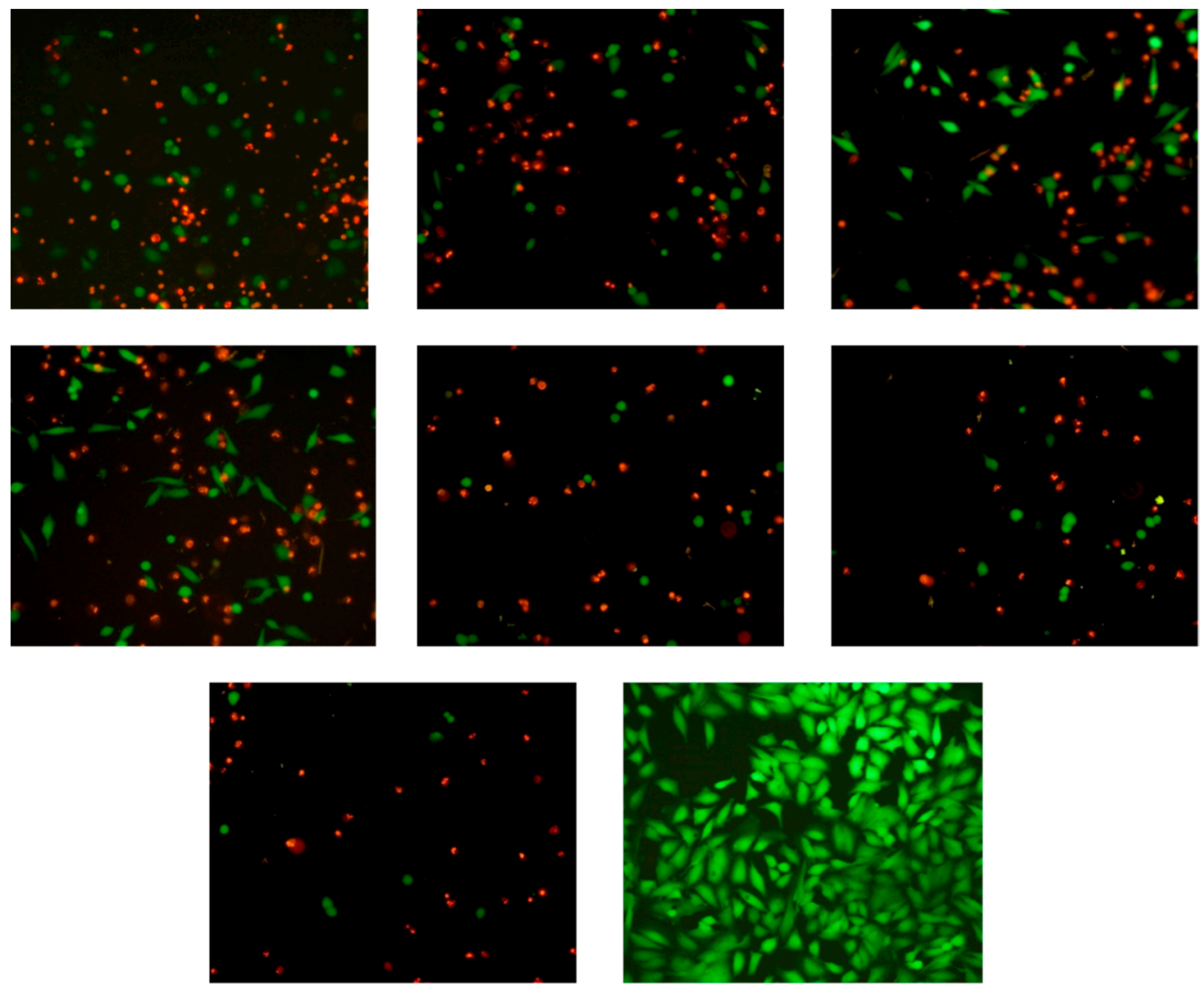

Figure 4. Viability of HeLa cells treated with $1 \mathrm{mg} / \mathrm{mL}$ of $\mathbf{4 a - c}, \mathbf{5 a}-\mathbf{d}$ for $24 \mathrm{~h}$. FDA/PI staining, 200×.

After $48 \mathrm{~h}$, at $100 \mu \mathrm{g} / \mathrm{mL}$, the compounds do not alter cell cycle phases of HeLa cells, but a fluctuation of the synthesis (S) phase is observed for HaCaT cells (Figure 5). 

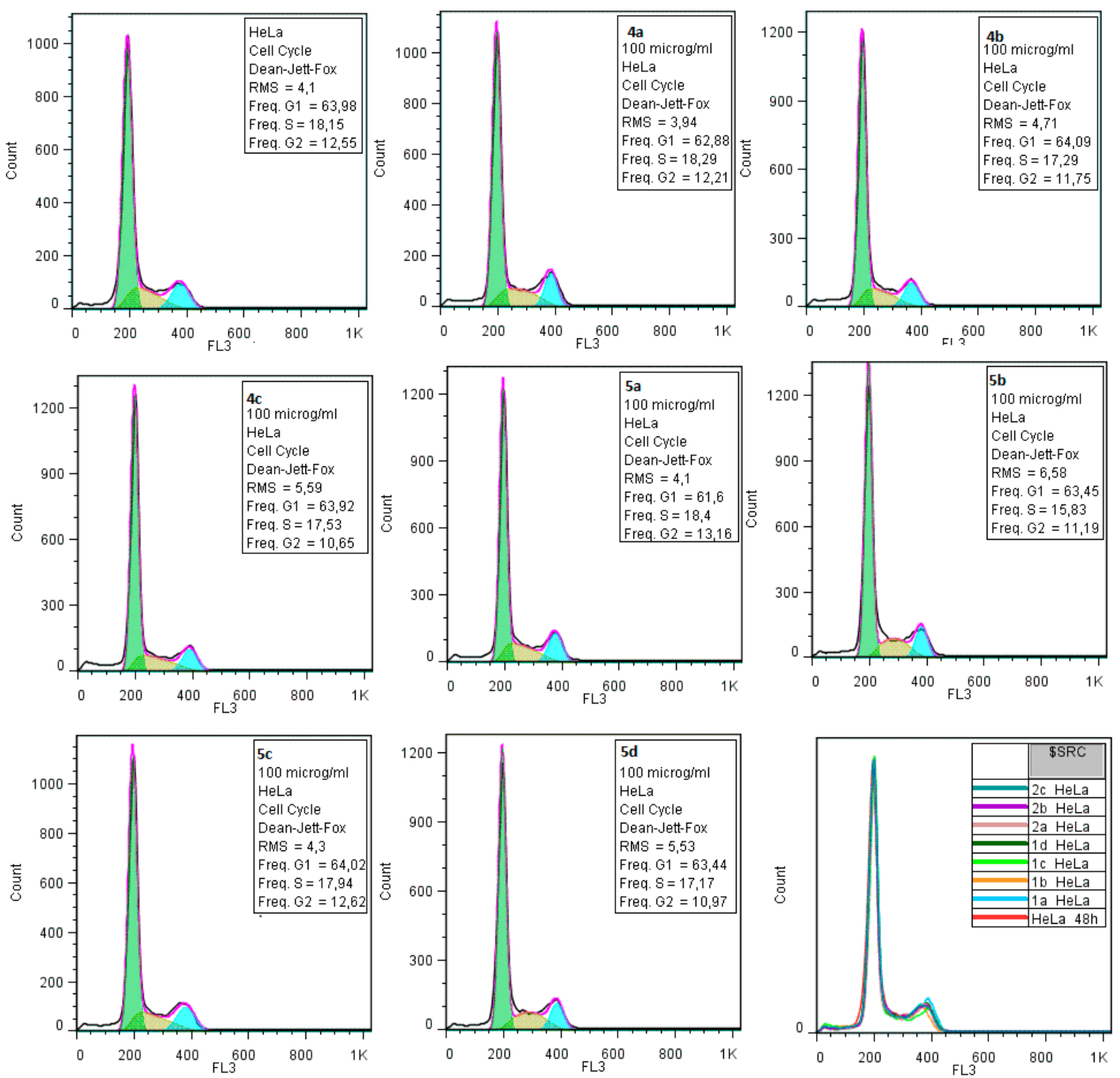

Figure 5. Flow cytometry histograms showing the influence of compounds $4 \mathbf{a}-\mathbf{c}, \mathbf{5 a}-\mathbf{d}$ on the cellular cycle of HeLa and HaCaT cells. Y axis-intensity of fluorescence; $X$ axis-the relative number of cells (15,000 events were investigated).

\subsection{In Silico Analyses}

The tested compounds comply with Lipinski rule and are predicted to have a good bioavailability according to the Veber rule (Table 4).

Table 4. Lipinski and Veber rules validation, bioavailability score and predicted molecular weight (MW).

\begin{tabular}{ccccc}
\hline Compound & Lipinski Rule & Veber Rule & Bioavailability Score & MW (g/mol) \\
\hline $\mathbf{4 a}$ & YES & YES & 0.55 & 391.85 \\
$\mathbf{4 b}$ & YES * & YES & 0.55 & 459.85 \\
$\mathbf{4 c}$ & YES * & YES & 0.55 & 426.30 \\
$\mathbf{5 a}$ & YES & YES & 0.55 & 373.83 \\
$\mathbf{5 b}$ & YES * & YES & 0.55 & 408.28 \\
$\mathbf{5 c}$ & YES & YES & 0.55 & 441.83 \\
$\mathbf{5 d}$ & YES & YES & 0.55 & 450.92 \\
Carprofen & YES & YES & 0.56 & 273.71 \\
\hline
\end{tabular}

${ }^{*} \mathbf{4} b, 4 c, 5 b$, and $5 d$ don't respect the LogP rule, being higher than 5 , but they respect the other criteria of the Lipinski rule. 
Regarding the predicted structural similarity of compounds $4 \mathbf{a}-\mathbf{c}$ and $5 \mathbf{a}-\mathbf{d}$ with other already known chemicals compounds, we noticed that compounds $1 \mathrm{a}$, c recorded a higher similarity with compound 2-(6-chloro-9H-carbazol-2-yl)- $\mathrm{N}$-phenylpropanamide, with biological activity, i.e., inhibition of Faah—fatty acid amide hydrolase active site (Table 5).

Table 5. Structural similarities.

\begin{tabular}{|c|c|c|c|c|}
\hline Compound & Similar Compound & Percent & Chemical Structure & Target Structure of Similar Compound \\
\hline $4 \mathbf{a}$ & $\begin{array}{l}\text { CHEMBL2171276* } \\
\text { CHEMBL2171249 } \\
\text { CHEMBL1316 }\end{array}$ & $\begin{array}{l}0.602 \\
0.585 \\
0.585\end{array}$ & 2-(6-chloro-9H-carbazol-2-yl)- $N$-phenylpropanamide * & $\begin{array}{l}\text { Faah inhibition-fatty acid amide hydrolase } \\
\text { (Norway rat) }\end{array}$ \\
\hline $4 \mathrm{c}$ & $\begin{array}{l}\text { CHEMBL2171276* } \\
\text { CHEMBL2171249 } \\
\text { CHEMBL1316 }\end{array}$ & $\begin{array}{l}0.590 \\
0.573 \\
0.573\end{array}$ & 2-(6-chloro-9H-carbazol-2-yl) - $N$-phenilpropanamide & $\begin{array}{l}\text { Faah inhibition-fatty acid amide hydrolase } \\
\text { (Norway rat) }\end{array}$ \\
\hline $5 \mathbf{b}$ & $\begin{array}{l}\text { CHEMBL380021* } \\
\text { CHEMBL2418797 }\end{array}$ & 0.594 & 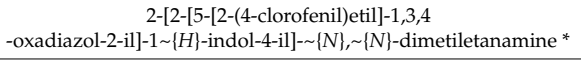 & nociceptive receptor ligand \\
\hline $5 c$ & $\begin{array}{l}\text { CHEMBL2418770* } \\
\text { CHEMBL380021 }\end{array}$ & $\begin{array}{l}0.587 \\
0.565\end{array}$ & $\begin{array}{c}\text { 2-(3 }\{H\} \text {-benzimidazol-5-yl)-5-[2-[4 } \\
\text {-(trifluoromethyl)phenyl]ethyl]-1,3,4-oxadiazole * }\end{array}$ & $\begin{array}{c}\text { QPCT-glutaminyl-peptide } \\
\text { cyclotransferase inhibition (human) }\end{array}$ \\
\hline
\end{tabular}

Considering that the structural similarities may induce similarities in biological activities, we identified the possible structural similarities of the analyzed compounds with other ligands (Table 5). Interesting results regarding structural similarity were observed for compounds 5a-c. While compounds $\mathbf{5 a}$ and $5 \mathbf{b}$ are similar with nociceptive receptor ligand 2-[2-[5[2-(4-clorofenil)etil]-1,3,4-oxadiazol-2-il]-1 $\{H\}$-indol-4-il]- $\{N\}, \sim\{N\}$-dimetiletanamine, compound $5 \mathbf{c}$ is similar with 2-(3 \{H\}-benzimidazol-5-yl)-5-[2-[4-(trifluoromethyl)phenyl]ethyl]-1,3,4 -oxadiazole, a cyclotransferase inhibitor.

For compound $\mathbf{5 d}$ we founded a poor similarity with other know compounds (Table 5).

Next, ADMET predictions suggest that all molecules have good intestinal absorption, with a value of more than $30 \%$ [23] (Table 6).

Table 6. Prediction of intestinal absorption, permeability of Caco2, blood-brain barrier (BBB) permeability, Renal OCT2.

\begin{tabular}{cccccccccc}
\hline Compound & $\mathbf{4 a}$ & $\mathbf{4 b}$ & $\mathbf{4 c}$ & $\mathbf{5 a}$ & $\mathbf{5 b}$ & $\mathbf{5 c}$ & $\mathbf{5 d}$ & Carprofen & Unit \\
\hline Intestinal absorption & 91 & 89 & 90 & 94 & 92 & 91 & 96 & 94 & $\%$ Absorption \\
Caco-2 pkCSM & 0.919 & 0.944 & 0.934 & 1.021 & 1.01 & 1.016 & 0.934 & 1.301 & $\begin{array}{c}\text { log Papp in } \\
\text { permeability }\end{array}$ \\
BBB permeability & -0.635 & -0.942 & -0.816 & 0.428 & 0.383 & 0.342 & -0.371 & 0.191 & log BB \\
Renal Substrate OCT2 & NO & NO & NO & NO & NO & NO & NO & NO & \\
\hline
\end{tabular}

The Caco2 cell line permeability suggesting if a compound is absorbed after oral administration revealed a value greater than 0.9 for all of the tested molecules [23]. The $\mathbf{5 a}, \mathbf{5 b}$, and $\mathbf{5 c}$ compounds have also shown an average blood brain barrier permeability. No drug-drug interactions affecting the renal clearance have been recorded for the tested compounds (Table 6).

The AMES tests that predicts the mutagenic potential [23] proved to be positive for all tested compounds (Table 7). 
Table 7. Toxicity descriptors.

\begin{tabular}{ccccccccc}
\hline Compound & $\mathbf{4 a}$ & $\mathbf{4 b}$ & $\mathbf{4 c}$ & $\mathbf{5 a}$ & $\mathbf{5 b}$ & $\mathbf{5 c}$ & $\mathbf{5 d}$ & Unit \\
\hline AMES toxicity & yes & yes & yes & yes & yes & yes & yes & Yes/No \\
DMT(human) & 0.19 & 0.13 & 0.16 & 0.41 & 0.36 & 0.33 & 0.503 & $\log \mathrm{mg} / \mathrm{kg} / \mathrm{day}$ \\
I. hERGI & no & no & no & no & no & no & no & Yes/No \\
I. hERGII & yes & yes & yes & yes & yes & yes & yes & Yes/No \\
LD 50 & 2.46 & 2.46 & 2.50 & 2.30 & 2.33 & 2.34 & 2.60 & $\mathrm{~mol} / \mathrm{kg}$ \\
Hepatotoxicity & yes & yes & yes & yes & yes & yes & yes & Yes/No \\
\hline
\end{tabular}

DMT—maximum tolerated human dose, I—inhibitor, LD—lethal dose.

The maximum tolerated predicted dose for humans is considered to be low for all the tested molecules, as shown in Table 7. The inhibition of potassium channels encoded by the hERG gene is the main cause of the development of QT interval prolongation, on the electrocardiogram. Predictions in the pkCSM database suggest that all molecules inhibit hERG II, and those in the admetSAR database suggest that all molecules have poor inhibitory activity on hERG I (Table 7). In terms of hepatotoxicity, predictions suggest that the studied molecules exhibit hepatotoxicity.

\section{Discussion}

We synthesized novel derivatives based on 6-chloro-9H-carbazol and 1,3,4-oxadiazol scaffolds. The chemical structures of the novel compounds (carprofen hydrazide, $N, N^{\prime}$-disubstituted hydrazine and 1,3,4-oxadiazoles derivatives) and the carprofen methyl ester were confirmed on the basis of spectral studies.

The biological activity data have shown that the synthesized compounds have a good antimicrobial activity, especially on Gram-negative strains, 4a showing the best activity against $E$. coli. In contrast, $5 \mathrm{c}$ is a potentially antifungal agent. It is to be highlighted that the obtained compounds acted preferentially on biofilm embedded cells, as revealed by the very low MBEC values obtained for some compound-microbial strain pairs, in comparison with the MIC and MBC values. Also, it is to be noticed the very good anti-biofilm activity of all tested compounds against the P. aeruginosa biofilm, well known for its high resistance to all currently available antimicrobial agents. The in vitro cytotoxicity of the tested compounds performed on two cellular lines (i.e., HeLa and HaCaT cells) reveal a dose- and time-related effect, the cellular viability decreasing with the increase of concentration $(>100 \mu \mathrm{g} / \mathrm{mL})$ and incubation time $(48 \mathrm{~h})$. However, at concentrations lower than $100 \mu \mathrm{g} / \mathrm{mL}$, the tested compounds do not induce cytotoxicity and do not alter the mammalian cell cycle.

The new synthesized compounds show good drug-like properties. All studied compounds comply with Lipinski rule and also, have a good predicted bioavailability according to the Veber rule.

To predict a possible biological activity of compounds $4 \mathbf{a}-\mathbf{c}$ and $\mathbf{5 a}-\mathbf{d}$, we evaluated by bioinformatics tools the molecular similarity of our compounds and other compounds, already included into most popular databases. Our results have shown that compounds $4 a-c$ exhibit a molecular similarity with Faah inhibitors, while the compounds $\mathbf{5 a - c}$, appeared to have nociceptive and QPCT—glutaminyl-peptide cyclotransferase inhibitory activities.

The organic cation transporter OCT2 is involved in the renal excretion of cationic drugs and raises the possibility of drug-drug interactions between an inhibitor and a substrate drug, which will have a decreased renal clearance [24].

The ADMET predictions show that the compounds may have good oral absorption. Plus, $\mathbf{5 a}, \mathbf{5} \mathbf{b}$, and $\mathbf{5 c}$ show an average permeability through the blood brain barrier. Unfortunately, the compounds may also have mutagenic potential and increased hepatotoxicity.

Research may continue in this direction, by synthesizing similar compounds with lower cytotoxic, mutagenic and hepatotoxic potential. 


\section{Materials and Methods}

\subsection{Measurements}

Melting points were determined in open glass capillary tube on an Electrothermal 9100 (Bibby Scientific Ltd., Stone, UK) capillary melting point apparatus and are uncorrected.

The FT-IR ATR (attenuated total reflection Fourier transform infrared) spectra were taken in solid state on a Bruker Vertex 70 spectrophotometer (Bruker Corporation, Billerica, MA, USA).

The ${ }^{1} \mathrm{H}-\mathrm{NMR}$ and ${ }^{13} \mathrm{C}-\mathrm{NMR}$ spectra were recorded in dimethylsulfoxide-d6 (DMSO- $d_{6}$ ) or deuterated chloroform on a Bruker Fourier $300 \mathrm{MHz}$ or Bruker AvanceIII $500 \mathrm{MHz}$ instrument (Bruker Corporation, Billerica, MA, USA), using tetramethylsilane as the internal standard, the chemical shifts are expressed in $\delta$ ppm.

The ${ }^{1} \mathrm{H}-\mathrm{NMR}$ data are reported in the following order: chemical shifts, multiplicity, the coupling constants, number of protons and signal/atom attribution. The apparent resonance multiplicity is described as s (singlet), d (doublet), q (quartet), m (multiplet), dd (double doublet), and br (broad) signal.

For the ${ }^{13} \mathrm{C}$-NMR data the order is the following: chemical shifts and signal/atom attribution.

The mass spectrum of compound $5 \mathbf{d}$ was recorded on a Maxis Bruker $4 \mathrm{G}$ spectrometer (Bruker Corporation, Billerica, MA, USA) with an electrospray ionization source (ESI). The samples were dissolved in DMSO $1 \mathrm{mg} / 1 \mathrm{~mL}$ and then the solution was diluted with methanol to a final concentration of $1 \mu \mathrm{g} / 1 \mathrm{~mL}$. The scanning range of molecular ions $(\mathrm{m} / \mathrm{z})$ was $50-1250$.

\subsection{Chemical Synthesis and Spectral Characterization}

\section{Methyl (2RS)-2-(6-chloro-9H-carbazol-2-yl)propanoat (carprofen methyl ester) (2)}

(RS)-2-(6-Chloro-9H-carbazol-2-yl)propanoic acid (carprofen) (10 g, $0.037 \mathrm{~mol}$ ) was dissolved with stirring in $400 \mathrm{~mL}$ methanol absolute. Then $1.2 \mathrm{~mL}$ concentrated sulfuric acid (98\%) was dropwise added as a catalyst and stirring was continued at room temperature for $8 \mathrm{~h}$. The reaction mixture was left overnight at room temperature, and then the methanol was evaporated at low pressure until a precipitate appeared. Over the reaction mixture, $200 \mathrm{~mL}$ of water was added and the precipitate was filtered off at low pressure and washed well with water on the filter to remove the acid traces. The white or slightly yellow precipitate was air dried for $24 \mathrm{~h}$.

We obtained $10 \mathrm{~g}$ (yield 95\%) of carprofen methyl ester (m.p. 107-110 ${ }^{\circ} \mathrm{C}$ ).

FT-IR (solid in ATR, $v \mathrm{~cm}^{-1}$ ): 3450w; 3405vs; 2983w; 2944w; 2875w; 1729vs; 1697m; 1624m; 1448m; 1429m; 1325w; 1269w; 1236w; 1193m; 1172m; 1093w; 1059m; 873w; 806m; 731w; 695w.

${ }^{1} \mathrm{H}-\mathrm{NMR}\left(\mathrm{CDCl}_{3}, \delta \mathrm{ppm}, J \mathrm{~Hz}\right): 8.26$ (brs, 1H, H-9); 7.96 (brs, 1H, H-5); 7.92 (d, 1H, J = 8.1 Hz, H-4); 7.33 (d, J = 8.6 Hz, 1H, H-8); 7.31 (brs, 1H, H-1); 7.25 (d, J = 8.1 Hz, 1H, H-3); 7.17 (d, 1H, H-7, 8.6); $3.90(\mathrm{q}, J=7.1 \mathrm{~Hz}, 1 \mathrm{H}, \mathrm{H}-10) ; 3.71$ (s, 3H, H-13); 1.60 (d, J = $7.1 \mathrm{~Hz}, 3 \mathrm{H}, \mathrm{H}-11)$;

${ }^{13} \mathrm{C}-\mathrm{NMR}\left(\mathrm{CDCl}_{3}, \delta \mathrm{ppm}\right): 175.49$ (C-12); 140.29 (C-8a); 139.01 (C-1a); 138.00 (C-2); 125.70 (C-7); 124.74 (C-5a); 124.11 (C-4a); 121.53 (C-6); 120.54 (C-4); 119.84 (C-5); 119.47 (C-3); 111.54 (C-8); 109.49 (C-1); 52.17 (C-13); 45.74 (C-10); 18.86 (C-11).

(2RS)-2-(6-chloro-9H-carbazol-2-yl)propanohydrazide (carprofen hydrazide) (3)

Carprofen methyl ester $(6 \mathrm{~g}, 0.021 \mathrm{~mol})$ in ethanol $96 \%$ or absolute $(40 \mathrm{~mL})$ is treated under magnetic stirring, with hydrazine hydrate $100 \%(7 \mathrm{~mL})$ and refluxed for $8 \mathrm{~h}$ with continuous stirring. Then the mixture is cooled and the carprofen hydrazide is filtered off at low pressure and washed with cold alcohol on the filter; $4.2 \mathrm{~g}$ of white carprofen hydrazide are obtained with a melting point of 241-243 ${ }^{\circ} \mathrm{C}$ (yield 70\%).

FT-IR (solid in ATR, $v \mathrm{~cm}^{-1}$ ): 3347s; 3260m; 2979w;2873w; 1632vs; 1517m; 1462s; 1428m; 1379w; 1338m; 1269m; 1238s; 1120w; 1061m; 988m; 926w; 885m; 828w; 800m; 733w; 690w.

${ }^{1} \mathrm{H}-\mathrm{NMR}\left(300 \mathrm{MHz}, \mathrm{dmso}-d_{6}, \delta \mathrm{ppm}, J \mathrm{~Hz}\right): 11.36$ (s, 1H, H-9); 9.24 (s, 1H, HN); 8.15 (d, J = 2.2 Hz, 1H, H-5); 8.05 (d, J = 8.2 Hz, 1H, H-4); 7.48 (d, J = 8.5 Hz, 1H, H-8); 7.47 (brs, 1H, H-1); 7.35 (dd, 
$J=2.2 \mathrm{~Hz}, J=8.5 \mathrm{~Hz}, 1 \mathrm{H}, \mathrm{H}-7) ; 7.16(\mathrm{dd}, J=1.4 \mathrm{~Hz}, J=8.2 \mathrm{~Hz}, 1 \mathrm{H}, \mathrm{H}-3) ; 4.21$ (brs, 2H, H-N); 3.70 (q, $J=6.9 \mathrm{~Hz}, 1 \mathrm{H}, \mathrm{H}-10) ; 1.42(\mathrm{~d}, J=6.9 \mathrm{~Hz}, 3 \mathrm{H}, \mathrm{H}-11)$;

${ }^{13} \mathrm{C}-\mathrm{NMR}\left(75 \mathrm{MHz}\right.$, dmso- $d_{6}, \delta$ ppm): 173.05 (C-12); 140.67 (C-8a); 140.56 (C-1a); 138.36 (C-2); 123.71 (C-5a); 123.56 (C-4a); 122.85 (C-6); 125.02 (C-7); 120.34 (C-4); 119.64 (C-5); 118.90 (C-3); 112.34 (C-8); 109.71 (C-1); 43.81 (C-10); 18.79 (C-11).

$\mathrm{N}-[(2 \mathrm{RS})-2-(6-$ chloro-9H-carbazol-2-yl)propanoyl]-N'-benzoylhydrazine (4a)

In a round bottomed flask equipped with stirrer, carprofen hydrazide $(0.86 \mathrm{~g}, 0.003 \mathrm{~mol})$ and benzoyl chloride $(0.42 \mathrm{~g}, 0.003 \mathrm{~mol})$ and anhydrous pyridine $(20 \mathrm{~mL})$ are introduced. The mixture was stirred at room temperature for $4 \mathrm{~h}$. After the reaction time has expired, the mixture was poured into a dilute, cold solution of hydrochloric acid $(40 \mathrm{~mL} 10 \% \mathrm{HCl}$ solution). A precipitate was obtained, isolated by filtration, washed on the filter with water and used in the steps in the raw state.

After drying, $1.02 \mathrm{~g}$ of $N, N^{\prime}$-disubstituted hydrazine were obtained, with a melting point (m.p.) of $262-263{ }^{\circ} \mathrm{C}$ at a yield of $87 \%$ toward hydrazide. The compound is soluble at room temperature in pyridine, dimethylsulfoxide, dimethylformamide, after heating in methanol, ethanol, isobutanol, and hardly soluble after heating in isopropanol, xylene, insoluble in ethyl acetate, hexane and water.

FT-IR (solid in ATR, $v \mathrm{~cm}^{-1}$ ): 3356s; 3215m; 3084w; 3024w; 2974w; 2934w; 1706vs; 1651vs; 1576m; 1466s; 1367w; 1273m; 1241m; 1180w; 1144w; 1066w; 947w; 890w; 804w; 739w; 705m; 647w; 601m.

${ }^{1} \mathrm{H}-\mathrm{NMR}\left(300 \mathrm{MHz}\right.$, dmso- $d_{6}, \delta$ ppm, J Hz): 11.38 (brs, $\left.1 \mathrm{H}, \mathrm{H}-9\right) ; 10.34$ (s, 1H, HN); 10.15 (s, 1H, $\mathrm{NH}) ; 8.17(\mathrm{~d}, J=1.5 \mathrm{~Hz}, 1 \mathrm{H}, \mathrm{H}-5) ; 8.09(\mathrm{dd}, J=1.5 \mathrm{~Hz}, J=8.1 \mathrm{~Hz}, 1 \mathrm{H}, \mathrm{H}-7) ; 7.86(\mathrm{~d}, J=8,1 \mathrm{~Hz}, 2 \mathrm{H}$, H-15, H-19); 7.58- 7.44 (m, 4H, H-4, H-16, H-17, H-18); 7.53 (sl, 1H, H-1); 7.35 (d, J = 8.1 Hz, 1H, H-8); $7.23(\mathrm{~d}, J=8.4 \mathrm{~Hz}, 1 \mathrm{H}, \mathrm{H}-3) ; 3.92(\mathrm{q}, J=6.9 \mathrm{~Hz}, 1 \mathrm{H}, \mathrm{H}-10) ; 1.50$ (d, $J=6.9 \mathrm{~Hz}, 3 \mathrm{H}, \mathrm{H}-11)$;

${ }^{13}$ C-NMR (75 MHz, dmso-d6, $\delta$ ppm): 172.74 (C-12); 165.93 (C-13); 140.28 (C-8a); 138.91 (C-1a); 138.11 (C-2); 132.32 (C-14); 131.70 (C-17); 128.35 (C-16, C-18); 127.30 (C-15, C-19); 124.93 (C-7); 123.53 (C-5a); 122.72 (C-4a); 120.30 (C-4); 120.26 (C-6); 119.56 (C-5); 118.89 (C-3); 112.20 (C-8); 109.72 (C-1); 43.56 (C-10); 18.85 (C-11).

$N-[(2 R S)-2-(6-c h l o r o-9 H$-carbazol-2-yl)propanoyl]-N'-(4-chlorobenzoyl)hydrazine (4b)

The compound was prepared by the method described for (4a), from 4-chlorobenzoyl chloride $(0.525 \mathrm{~g}, 0.003 \mathrm{~mol})$.

There were obtained $1.04 \mathrm{~g}$ of compound (81\% yield toward hydrazide), with m.p. $268-270{ }^{\circ} \mathrm{C}$.

The compound is soluble at room temperature in pyridine, dimethylsulfoxide, dimethylformamide, after heating in isobutanol, hardly soluble after heating in methanol, ethanol, isopropanol, ethyl acetate, and insoluble in xylene, hexane and water.

FT-IR (solid in ATR, $v \mathrm{~cm}^{-1}$ ): 3414w; 3201m; 1599vs; 1567m; 1454m; 1273w; 1221w; 1152w; 1093w; $848 \mathrm{w} ; 802 \mathrm{w} ; 754 \mathrm{w} ; 730 \mathrm{w} ; 659 \mathrm{w}$.

${ }^{1} \mathrm{H}-\mathrm{NMR}\left(500 \mathrm{MHz}\right.$, dmso- $\left.d_{6}, \delta \mathrm{ppm}, J \mathrm{~Hz}\right): 11.41$ (brs, $\left.1 \mathrm{H}, \mathrm{H}-9\right) ; 10.46$ (s, $\left.1 \mathrm{H}, \mathrm{HN}\right) ; 10.21$ (s, $1 \mathrm{H}$, $\mathrm{NH}) ; 8.17(\mathrm{~d}, J=2.1 \mathrm{~Hz}, 1 \mathrm{H}, \mathrm{H}-5) ; 8.09(\mathrm{~d}, J=8.1 \mathrm{~Hz}, 1 \mathrm{H}, \mathrm{H}-4) ; 7.87$ (d, J = 8.1 Hz, 2H, H-15, H-19); 7.56 (d, $J=8,1 \mathrm{~Hz}, 2 \mathrm{H}, \mathrm{H}-16, \mathrm{H}-18) ; 7.52$ (d, $J=1.3 \mathrm{~Hz}, 1 \mathrm{H}, \mathrm{H}-1) ; 7.48$ (d, $J=8.7 \mathrm{~Hz}, 1 \mathrm{H}, \mathrm{H}-8) ; 7.36$ (dd, $J=2.1 \mathrm{~Hz}, J=8.7 \mathrm{~Hz}, 1 \mathrm{H}, \mathrm{H}-7) ; 7.22(\mathrm{dd}, J=1.3 \mathrm{~Hz}, J=8.1 \mathrm{~Hz}, 1 \mathrm{H}, \mathrm{H}-3) ; 3.93(\mathrm{q}, J=6.9 \mathrm{~Hz}, 1 \mathrm{H}, \mathrm{H}-10)$; $1.49(\mathrm{~d}, J=6.9 \mathrm{~Hz}, 3 \mathrm{H}, \mathrm{H}-11)$;

${ }^{13}$ C-NMR (125 MHz, dmso- $d_{6}, \delta$ ppm): 172.90 (C-12); 164.49 (C-13); 140.55 (C-8a); 139.98 (C-1a); 138.38 (C-2); 136.69 (C-17); 131.16 (C-14); 129.35 (C-15, C-19); 128.63 (C-16, C-18); 125.06 (C-7); 123.62 (C-4a); 122.83 (C-5a); 120.43 (C-4); 120.37 (C-6); 119.67 (C-5); 118.97 (C-3); 112.31 (C-8); 109.81 (C-1); 43.57 (C-10); 18.83 (C-11).

$\mathrm{N}$-[(2RS)-2-(6-chloro-9H-carbazol-2-yl)propanoyl]-N'-(3-trifluoromethylbenzoyl)hydrazine (4c)

Following the synthesis procedure described for (4a), using of 3-trifluoromethylbenzoyl chloride $(0.625 \mathrm{~g}, 0.003 \mathrm{~mol})$, there were obtained $1.06 \mathrm{~g}$ of the compound, resulted after recrystallization from isopropanol:water 1:3, yield 77\% toward hydrazide, m.p. $216-219^{\circ} \mathrm{C}$. 
The compound is soluble at room temperature in pyridine, dimethylsulfoxide, dimethylformamide, ethyl acetate, methanol, ethanol, after heating in isopropanol, isobutanol, xylene and insoluble in hexane and water.

FT-IR (solid in ATR, $v \mathrm{~cm}^{-1}$ ): 3405m; 3357vs; 3209m; 3079w; 3023w; 2967w; 2932w; 1708vs; 1649vs; 1550w; 1474m; 1449m; 1331s; 1273m; 1225m; 1174s; 1125s; 1071m; 923w; 880w; 818w; 742w; $693 \mathrm{~m} ; 603 \mathrm{~m}$;

${ }^{1} \mathrm{H}-\mathrm{NMR}\left(500 \mathrm{MHz}, \mathrm{dmso}-d_{6}, \delta \mathrm{ppm}, J \mathrm{~Hz}\right): 11.38$ (s, 1H, HN-9); 10.66 (brs, 1H, HN); 10.29 (s, 1H, $\mathrm{NH}) ; 8.20$ (brs, $1 \mathrm{H}, \mathrm{H}-15) ; 8.17$ (d, $J=1.9 \mathrm{~Hz}, 1 \mathrm{H}, \mathrm{H}-5) ; 8.16$ (d, J =8.1 Hz, 1H, H-19); 8.09 (d, J = 8.1 Hz, $1 \mathrm{H}, \mathrm{H}-4) ; 7.95$ (dl, J = 8.1 Hz, 1H, H-17); 7.75 (tl, J = 8.1 Hz, 1H, H-18); 7.53 (brs, 1H, H-1); 7.48 (d, $J=8.6 \mathrm{~Hz}, 1 \mathrm{H}, \mathrm{H}-8) ; 7.36(\mathrm{dd}, J=1.9 \mathrm{~Hz}, J=8.6 \mathrm{~Hz}, 1 \mathrm{H}, \mathrm{H}-7) ; 7.22(\mathrm{dd}, J=1.3 \mathrm{~Hz}, J=8.1 \mathrm{~Hz}, 1 \mathrm{H}, \mathrm{H}-3)$; $3.94(\mathrm{q}, J=7.0 \mathrm{~Hz}, 1 \mathrm{H}, \mathrm{H}-10) ; 1.49$ (d, $J=7.0 \mathrm{~Hz}, 3 \mathrm{H}, \mathrm{H}-11)$;

${ }^{13} \mathrm{C}-\mathrm{NMR}$ (125 MHz, dmso-d 6 , $\delta$ ppm): 172.82 (C-12); 164.00 (C-13); 140.53 (C-8a); 139.94 (C-1a); 138.36 (C-2); 133.29 (C-14); 131.53 (C-19); 130.06 (C-18); 129.52 (q, J(3F-C ${ }^{16}$ )=31.7 Hz, C-16); 128.43 $\left(\mathrm{q}, J\left(\mathrm{~F}-\mathrm{C}^{17}\right)=3.8 \mathrm{~Hz}, \mathrm{C}-17\right) ; 125.02(\mathrm{C}-7) ; 124.05\left(\mathrm{q}, J\left(\mathrm{~F}-\mathrm{C}^{15}\right)=3.8 \mathrm{~Hz}, \mathrm{C}-15\right) ; 123.88(\mathrm{C}-4 \mathrm{a}) ; 123.70(\mathrm{q}$, $\left.J(3 \mathrm{~F}-\mathrm{C})=267.8 \mathrm{~Hz},-\mathrm{CF}_{3}\right) ; 123.63(\mathrm{C}-5 \mathrm{a}) ; 120.40$ (C-6); 120.45 (C-4); 119.65 (C-5); 118.91 (C-3); 112.33 (C-8); 109.83 (C-1); 43.56 (C-10); 18.78 (C-11).

\section{(RS)-1-(6-chloro-9H-carbazol-2-yl)-1-(5-phenyl-1,3,4-oxadiazol-2-yl)ethane (5a)}

An amount of $0.784 \mathrm{~g}(0.002 \mathrm{~mol})$ of corresponding acylhydrazide (4a) and $8 \mathrm{~mL}$ of phosphorus oxychloride were introduced in a round bottom flask equipped with a reflux condenser to which a calcium chloride tube was attached. The mixture was heated on the water bath for $9 \mathrm{~h}$, then cooled and poured, under stirring, over ice water. The resulting precipitate was filtered off, washed with water and recrystallized from isopropanol:water 1:2.5.

An amount of $0.48 \mathrm{~g}$ of the compound is obtained, yield $64 \%$ toward acyl hydrazide with m.p. $\quad 185-186.5{ }^{\circ} \mathrm{C}$, soluble at room temperature in pyridine, ethyl acetate, dimethylsulfoxide, dimethylformamide, after heating in methanol, ethanol, isopropanol, isobutanol, xylene and insoluble in hexane and water.

FT-IR (solid in ATR, $v \mathrm{~cm}^{-1}$ ):3238s; 2979w; 2940w; 2780w; 1609m; 1551s; 1454vs; 1375w; 1330w; 1268s; 1244m; 1210m; 1062m; 1017w; 925w; 887w; 816m; 775w; 752m; 685s; 649w; 621m.

${ }^{1} \mathrm{H}-\mathrm{NMR}\left(300 \mathrm{MHz}, \mathrm{CDCl}_{3}, \delta\right.$ ppm, J Hz): 8.70 (brs, 1H, H-9, deuterable); 8.01- 7.94 (m, 4H, H-4, H-7, H-15, H-19); 7.52 - 7.39 (m, 4H, H-3, H-16, H-17, H-18); 7.33 (brs, 2H, H-1, H-5); 7.26 (d, J = 8.1 Hz, $1 \mathrm{H}, \mathrm{H}-8) ; 4.58$ (q, J = $7.2 \mathrm{~Hz}, 1 \mathrm{H}, \mathrm{H}-10) ; 1.90$ (d, J = 7.2 Hz, 3H, H-11);

${ }^{13} \mathrm{C}-\mathrm{NMR}$ (75 MHz, CDCl $\left.3, \delta \mathrm{ppm}\right): 169.17$ (C-12); 165.10 (C-13); 140.51 (C-8a); 138.77 (C-2); 138.24 (C-1a); 131.71 (C-17); 129.00 (C-16, C-18); 126.87 (C-15, C-19); 125.96 (C-7); 124.90 (C-14); 124.10 (C-5a); 123.82 (C-4a); 121.91 (C-6); 120.89 (C-4); 119.98 (C-5); 119.18 (C-3); 111.75 (C-8); 109.58 (C-1); 38.01 (C-10); 20.04 (C-11).

(RS)-1-(6-chloro-9H-carbazol-2-yl)-1-(5-(4-chlorophenyl)-1,3,4-oxadiazol-2-yl)ethane (5b)

The synthesis followed the procedure described for the preparation of compound 5a, using corresponding acyl hydrazide (4b) $(0.819 \mathrm{~g}, 0.002 \mathrm{~mol})$. Purification was done from isopropanol.

An amount of $0.56 \mathrm{~g}$ of the compound was obtained, yield $69 \%$ toward acyl hydrazide with m.p. $200-204{ }^{\circ} \mathrm{C}$, soluble at room temperature in pyridine, ethyl acetate, dimethylsulfoxide, dimethylformamide, after heating in ethanol, isopropanol, isobutanol, xylene, hardly soluble after heating in methanol and insoluble in hexane and water.

FT-IR (solid in ATR, $v \mathrm{~cm}^{-1}$ ): 3268m; 3088w; 2978w; 1606s; 1563m; 1481vs; 1462s; 1432m; 1408w; 1338w; 1274s; 1246m; 1095m; 1063m; 1013m; 873w; 834m; 817s; 792m; 627w;

${ }^{1} \mathrm{H}-\mathrm{NMR}\left(300 \mathrm{MHz}\right.$, dmso- $\left.d_{6}, \delta \mathrm{ppm}, J \mathrm{~Hz}\right): 11.41$ (s, 1H, H-9); 8.18 (d, J = $\left.2.2 \mathrm{~Hz}, 1 \mathrm{H}, \mathrm{H}-5\right) ; 8.13$ (d, $J=8.2 \mathrm{~Hz}, 1 \mathrm{H}, \mathrm{H}-4) ; 7.93$ (d, J = 8.8 Hz, 2H, H-15, H-19); 7.61 (d, J = 8.8 Hz, 2H, H-16, H-18); 7.48 (d, $J=8.8 \mathrm{~Hz}, 1 \mathrm{H}, \mathrm{H}-8) ; 7.46(\mathrm{~d}, J=1.3 \mathrm{~Hz}, 1 \mathrm{H}, \mathrm{H}-1) ; 7.36(\mathrm{dd}, J=2.2 \mathrm{~Hz}, J=8.8 \mathrm{~Hz}, 1 \mathrm{H}, \mathrm{H}-7) ; 7.18$ (dd, $J=1.6 \mathrm{~Hz}, J=8.2 \mathrm{~Hz}, 1 \mathrm{H}, \mathrm{H}-3) ; 4.73(\mathrm{q}, J=7.2 \mathrm{~Hz}, 1 \mathrm{H}, \mathrm{H}-10) ; 1.79$ (d, $J=7.2 \mathrm{~Hz}, 3 \mathrm{H}, \mathrm{H}-11)$; 
${ }^{13} \mathrm{C}-\mathrm{NMR}$ (75 MHz, dmso-d $\left.d_{6}, \delta \mathrm{ppm}\right): 169.18$ (C-12); 163.39 (C-13); 140.57 (C-8a); 138.98 (C-1a); 138.42 (C-2); 136.61 (C-14); 129.56 (C-15, C-19); 128.22 (C-16, C-18); 125.33 (C-7); 123.46 (C-4a); 122.99 (C-5a); 122.21 (C-17); 121.14 (C-4); 120.82 (C-6); 119.77 (C-5); 118.38 (C-3); 112.44 (C-8); 109.83 (C-1); 36.95 (C-10); 19.91 (C-11).

(RS)-1-(6-chloro-9H-carbazol-2-yl)-1-(5-(3-trifluoromethylphenyl)-1,3,4-oxadiazol-2-yl)ethane (5c)

Following the synthesis procedure described for the preparation of compound 5a, of the corresponding acyl hydrazide (4c) (0.919 g $0.002 \mathrm{~mol}$ ) were used. Purification was done from isopropanol.

An amount of $0.55 \mathrm{~g}$ of compound was obtained, $62 \%$ toward acyl hydrazide, m.p. $169-172{ }^{\circ} \mathrm{C}$, soluble at room temperature in pyridine, ethyl acetate, dimethylsulfoxide, dimethylformamide, after heating in methanol, ethanol, isopropanol, isobutanol, xylene and insoluble in hexane and water.

FT-IR (solid in ATR, $v \mathrm{~cm}^{-1}$ ): 3416w; 3239w; 3083w; 2984w; 1616w; 1559m; 1469m; 1428m; 1378w; 1328s; 1272m; 1244m; 1170m; 1131vs; 1068m; 1014w; 971w; 927w; 869w; 811m; 752w; 732w; 697m.

${ }^{1} \mathrm{H}-\mathrm{NMR}\left(500 \mathrm{MHz}, \mathrm{dmso}-d_{6}, \delta \mathrm{ppm}, J \mathrm{~Hz}\right): 11.40$ (brs, $\left.1 \mathrm{H}, \mathrm{H}-9\right) ; 8.22$ (d, J = $\left.7.9 \mathrm{~Hz}, 1 \mathrm{H}, \mathrm{H}-19\right)$; 8.18 (brs, 1H, H-15); 8.17 (s, 1H, H-5); 8.13 (d, J = 8.1 Hz, 1H, H-8); 7.96 (brd, J = 7.9 Hz, 1H, H-17); 7.79 $(\mathrm{t}, J=7.9 \mathrm{~Hz}, 1 \mathrm{H}, \mathrm{H}-18) ; 7.48(\mathrm{~s}, 1 \mathrm{H}, \mathrm{H}-1) ; 7.48$ (d, $J=8.5 \mathrm{~Hz}, 1 \mathrm{H}, \mathrm{H}-4) ; 7.36$ (dd, $J=2.1 \mathrm{~Hz}, J=8.5 \mathrm{~Hz}$, $1 \mathrm{H}, \mathrm{H}-7) ; 7.19(\mathrm{dd}, J=1.3 \mathrm{~Hz}, J=8.1 \mathrm{~Hz}, 1 \mathrm{H}, \mathrm{H}-3) ; 4.76$ (q, $J=7.2 \mathrm{~Hz}, 1 \mathrm{H}, \mathrm{H}-10) ; 1.80(\mathrm{~d}, J=7.2 \mathrm{~Hz}, 3 \mathrm{H}$, H-11);

${ }^{13} \mathrm{C}-\mathrm{NMR}\left(125 \mathrm{MHz}, \mathrm{dmso}-d_{6}, \delta \mathrm{ppm}\right): 169.54$ (C-12); 163.08 (C-13); 140.43 (C-8a); 138.94 (C-1a); 138.29 (C-2); 130.85 (C-18); $130.44(\mathrm{C}-19) ; 130.08\left(\mathrm{q}, J\left(3 \mathrm{~F}-\mathrm{C}^{16}\right)=32.5 \mathrm{~Hz}, \mathrm{C}-16\right) ; 128.37\left(\mathrm{q}, J\left(3 \mathrm{~F}-\mathrm{C}^{17}\right)=3.8 \mathrm{~Hz}\right.$, C-17); 125.35 (C-7); 124.45 (C-14); 123.60 (q, J(3F-C)=212.5 Hz, -CF $) ; 123.47$ (C-4a); 123.43 (C-5a); 122.73 $\left(\mathrm{q}, J\left(3 \mathrm{~F}-\mathrm{C}^{15}\right)=3.8 \mathrm{~Hz}, \mathrm{C}-15\right) ; 121.14$ (C-4); 120.84 (C-6); 119.78 (C-5); 118.42 (C-3); 112.41 (C-8); 109.82 (C-1); 36.98(C-10); 19.99 (C-11).

(RS)-1-(6-chloro-9H-carbazol-2-yl)-1-[5-(4-pyridil)-1,3,4-oxadiazol-2-yl]ethane (5d)

To a round bottom flask equipped with a stirrer bar and a condenser was introduced in sequence, $\mathrm{POCl}_{3}(2 \mathrm{~mL})$, carprofen $(0.273 \mathrm{~g}, 0.001 \mathrm{~mol})$, and isoniazid $(0.001 \mathrm{~mol})$. The mixture was stirred for a few minutes and then heated under reflux for $2.5 \mathrm{~h}$. Benzene or toluene $(10 \mathrm{~mL})$ was added and the mixture evaporated under reduced pressure on a rotary evaporator. The residue was treated with ice-water (10 g) and the red brick precipitate was filtered off under vacuum and washed several times with cold water (ice water). The orange product was crystallized from a mixture water/ethanol (2:1).

An amount of $0.34 \mathrm{~g}$ compound $\left(\mathrm{C}_{21} \mathrm{H}_{15} \mathrm{ON} \mathrm{ON}_{4} \mathrm{Cl}\right)$ was obtained, with yield $91 \%$ toward carprofen, m.p. $173-175^{\circ} \mathrm{C}$, soluble at room temperature in acetone, dimethylsulfoxide, dimethylformamide, and 1:1 dichloromethane: methanol, by heating in methanol, benzene, hexane, dichloromethane, dimethylsulphoxide, hardly soluble by heating in ethanol, chloroform, toluene, petroleum ether, and insoluble in xylene, ethyl ether, ethyl acetate and water.

FT-IR (solid in ATR, $v \mathrm{~cm}^{-1}$ ): 3241m; 3104w; 2979w; 2934w; 1691m; 1610w; 1551m; 1473vs; 1461vs; 1432m; 1358w; 1337w; 1273vs; 1217m; 1173m; 1065s; 928w; 871w; 817m; 753w; 699w; 584w.

${ }^{1} \mathrm{H}-\mathrm{NMR}\left(500 \mathrm{MHz}, \mathrm{CDCl}_{3}, \delta \mathrm{ppm}, J \mathrm{~Hz}\right): 11.41$ (s, $\left.1 \mathrm{H}, \mathrm{H}-9\right) ; 8.80$ (dd, J = $1.6 \mathrm{~Hz}, J=8.2 \mathrm{~Hz}, 2 \mathrm{H}$, H-16, H-18); 8.19 (s, 1H, H-5); 8.13- 8.19 (m, 2H, H-15, H-19); 7.90 (d, J = 8.4 Hz, 1H, H-8); 7.49 (s, $1 \mathrm{H}$, $\mathrm{H}-1) ; 7.48(\mathrm{~d}, J=8.5 \mathrm{~Hz}, 1 \mathrm{H}, \mathrm{H}-4) ; 7.36(\mathrm{dd}, J=1.8 \mathrm{~Hz}, J=8.4 \mathrm{~Hz}, 1 \mathrm{H}, \mathrm{H}-7) ; 7.18$ (d, J = 8.5 Hz, 1H, H-3); $4.80(\mathrm{q}, \mathrm{J}=7.2 \mathrm{~Hz}, 1 \mathrm{H}, \mathrm{H}-10) ; 1.80(\mathrm{~d}, \mathrm{~J}=7.2 \mathrm{~Hz}, 3 \mathrm{H}, \mathrm{H}-11)$;

${ }^{13} \mathrm{C}-\mathrm{NMR}\left(125 \mathrm{MHz}, \mathrm{CDCl}_{3}, \delta \mathrm{ppm}\right): 170.03$ (C-12); 162.65 (C-13); 150.74 (C-16, C-18); 140.56 (C-8a); 138.79 (C-1a); 130.65 (C-2); 125.86 (C-7); 125.36 (C-14); 123.45 (C-4a); 123.0 (C-5a); 122.99 (C-4); 120.86 (C-6); 120.28 (C-15, C-19), 120.20 (C-5); 118.41 (C-3); 112.47 (C-8); 109.90 (C-1); 36.98 (C-10); $19.50(\mathrm{C}-11)$.

In order to confirm the structure, the compound $\mathbf{5 d}$ was also analyzed by mass spectroscopy, revealing the appearance of a peak corresponding to the molecular ion $375.1[\mathrm{M}+\mathrm{H}]$, which confirms the molecular weight of this compound. 


\subsection{Antimicrobial Activity Assay}

The antimicrobial activity of the synthesized compounds was determined using three methods, against a panel of Gram-negative (Escherichia coli ATCC 25922, Pseudomonas aeruginosa ATCC 27853) and Gram-positive (Staphylococcus aureus ATCC 25923, Enterococcus faecalis ATCC 29212) bacteria, as well as the fungal strain Candida albicans ATCC 90029.

Minimal inhibitory concentration (MIC) assay: The minimum amount of the tested compounds that inhibited the microbial growth was evaluated using the microdilution method in liquid Mueller Hinton medium. The tested binary concentrations in the range of $5-0.009 \mathrm{mg} / \mathrm{mL}$ were achieved starting from a stock solution prepared in DMSO of $10 \mathrm{mg} / \mathrm{mL}$, in a $100 \mu \mathrm{L}$ culture medium final volume, seeded with a $20 \mu \mathrm{L}$ microbial suspension of $0.5 \mathrm{MacFarland}$ density. In each test, a microbial culture positive control and a sterile medium negative control were performed. The plates were incubated for $24 \mathrm{~h}$ at $37^{\circ} \mathrm{C}$. The results are shown in Table 1 [25-27].

Minimal bactericidal concentration (MBC) assay: after reading the MIC value, a volume of $10 \mu \mathrm{L}$ from the well corresponding to the MIC value and from all the previous wells was seeded on solid PCA (plate count agar) medium to determine the MBC value, corresponding to the concentration at which the total inhibition of microbial growth on the solid medium was obtained (Table 2).

Anti-biofilm activity assay: the plates used to determine the MIC and MBC were washed two to three times with sterile saline to remove free and poorly adherent cells, after which the biofilms formed on the walls of the wells were fixed for 5 min with $100 \mu \mathrm{L}$ of cold methanol, stained with $1 \%$ alkaline crystal violet solution for $15 \mathrm{~min}$ and then resuspended in acetic acid solution $33 \%$. After homogenizing the colored suspension, its optical density was measured at $490 \mathrm{~nm}$. The minimal biofilm eradication concentration (CMEB) was determined to be the lowest concentration of the tested compounds at which the decrease in absorbance value, measured at $490 \mathrm{~nm}$, was observed in comparison to the positive control (Table 3) [28].

\subsection{In Vitro Cytotoxicity Assay}

The cell cultures used in this study were HeLa $\left(\mathrm{ATCC}^{\circledR}\right.$ CCL-2 $\left.{ }^{\mathrm{TM}}\right)$ and the HaCaT immortalized keratinocyte line. They were maintained in DMEM: F12 medium supplemented with $10 \%$ fetal bovine serum.

The compounds $\mathbf{4 a - c}, \mathbf{5 a}-\mathbf{d}$ were diluted in DMSO at a concentration of $20 \mathrm{mg} / \mathrm{mL}$ and brought to a concentration of $2 \mathrm{mg} / \mathrm{mL}$ in DMEM: F12. The solutions were sterilized by using a $0.22 \mu \mathrm{m}$ filter.

\subsubsection{Evaluation of Cytotoxicity Using CellTiter $96^{\circledR}$ AQueous One Solution Cell Proliferation Assay}

The cells were seeded at a density of $7.5 \times 10^{4} /$ well, in 96-well plates, in the presence of different concentrations of the tested compounds, ranging from $500 \mu \mathrm{g} / \mathrm{mL}$ to $15.75 \mu \mathrm{g} / \mathrm{mL}$. After $48 \mathrm{~h}$, the effect of the compounds was evaluated by the addition of tetrazolium salt, 3-(4,5-dimethylthiazol-2-yl)-5-(3-carboxymethoxyphenyl)-2-(4-sulfophenyl)-2H-tetrazolium. Toxicity assessment was performed at $2 \mathrm{~h}$, by reading the absorbance at $490 \mathrm{~nm}$, using the Tristar Berthold Technologies spectrophotometer (Berthold Technologies, Bad Wildbad, Germany).

\subsubsection{Toxicity Assessment Using Fluorescein Diacetate Staining (FDA)-Propidium Iodide (PI)}

The cells were seeded at a density of $7.5 \times 10^{5} /$ well in 24-well plates. The medium contained $1 \mathrm{mg} / \mathrm{mL}$ compound. After $24 \mathrm{~h}$, cell viability was assessed by staining with FDA $(10 \mu \mathrm{g} / \mathrm{mL})$ and PI $(20 \mu \mathrm{g} / \mathrm{mL})$. Cells were observed on the Zeiss fluorescence microscope (Gottingen, Germany).

\subsubsection{Evaluation of the Cellular Cycle}

The cells were seeded at a density of $7.5 \times 10^{5} /$ well in 24 -well plates and maintained in culture medium containing the tested compounds, at a concentration of $100 \mu \mathrm{g} / \mathrm{mL}$, for $48 \mathrm{~h}$. After incubation, the cells were trypsinized, washed in phosphate buffer saline, fixed in $70 \%$ cold ethanol and stained 
with $50 \mu \mathrm{g} / \mathrm{mL}$ propidium iodide solution. The evaluation was performed using the Beckman Coulter XLM flow cytometer (Winooski, VT, USA) and Flow Jo7 software (version 7.0 Copyright@; 2018 [or current year of copyright] Partek Inc., St. Louis, MO, USA).

\subsection{In Silico Biopharmaceutical Study of the Compounds $4 \mathbf{4 a - c , 5 a - c}$}

\subsubsection{Molecular Modeling of Compounds}

The series of molecules were modeled in the Discovery Studio software (Dassault Systèmes BIOVIA, Discovery Studio Modeling Environment, Release 2017, San Diego, CA, USA: Dassault Systèmes, 2016), using carprofen as template compound. The analysis consisted of modeling 2D structures, adding specific substituents and completing valences with hydrogen atoms and passing these structures into three-dimensional space, in order to obtain 3D spatial structures.

\subsubsection{Energy Minimization}

Minimization of these molecules was done using the Hamiltonian method: Forcefield MMFF94x at a gradient of 0.05. After calculating the minimum energy, the Gasteiger partial loads (PEOE) were applied.

\subsubsection{Determination of Drug-Like Character and Bioavailability}

For establishing the pharmacological character of the newly synthesized compounds, the compliance with at least two Lipinski rules (drug-like nature) and with the Veber rule (bioavailability) was checked $[29,30]$.

\subsubsection{Structural Similarities Using Chemical Compounds Database}

By accessing the Expasy/medicinal chemistry database we identified the possible structural similarities of the analyzed compounds with other chemical compounds.

\subsubsection{Identifying the Pharmacokinetic Profile}

For the ADME prediction, a pkCSM platform was used [23], and for their toxicity, results from multiple database were compared [30,31].

We have selected the following properties: 1. Intestinal absorption, 2. blood-brain barrier permeability (BBB), 3. central nervous system permeability (CNS), 4. AMES toxicity, 5. maximum tolerated human dose, ability to inhibit human ether-a-gogo gene (hERG I and hERG II), 6. Lethal Dose 50 (on rat), 7. hepatotoxicity, 8 . the ability of the substance to produce carcinogenic effects.

Author Contributions: Conceptualization, C.L., D.C.N., C.B., A.T.B.T., and M.C.C.; methodology, A.T.B.T., F.D., I.Z., P.I., C.D.B., software, S.A., validation, C.L., M.T.C., F.D., writing-original draft preparation, C.L.; writing-review and editing, F.D., C.L., visualization, M.C.C., supervision, C.L., F.D. All authors have read and agreed to the published version of the manuscript.

Funding: The financial support of the research project 52PCCDI/2018 and PDI-PFE-CDI ID 335 projects within PNCDI III developed with the support of ANCSI is gratefully acknowledged.

Conflicts of Interest: The authors declare no conflict of interest.

\section{References}

1. Salih, N.; Salimon, J.; Yousif, E. Synthesis and antimicrobial activities of $9 H$-carbazole derivatives. Arab. J. Chem. 2016, 9, 781-786. [CrossRef]

2. Knölker, H.J.; Reddy, K.R. Isolation and synthesis of biologically active carbazole alkaloids. Chem. Rev. 2002, 102, 4303. [CrossRef] [PubMed]

3. Montoia, A.; e Silva, L.F.R.; Torres, Z.E.; Costa, D.S.; Henrique, M.C.; Lima, E.S.; Vasconcellos, M.C.; Souza, R.C.; Costa, M.R.; Grafov, A.; et al. Antiplasmodial activity of synthetic ellipticine derivatives and an isolated analog. Bioorg. Med. Chem. Lett. 2014, 24, 2631-2634. [CrossRef] [PubMed] 
4. Patel, O.P.S.; Mishra, A.; Maurya, R.; Saini, D.; Pandey, J.; Taneja, I.; Raju, K.S.R.; Kanojiya, S.; Shukla, S.K.; Srivastava, M.N.; et al. Naturally occurring carbazole alkaloids from Murraya koenigii as potential antidiabetic agents. J. Nat. Prod. 2016, 79, 1276-1284. [CrossRef] [PubMed]

5. Ruegg, U.T.; Burgess, G.M. Staurosporine, K-252 and UCN-01: Potent but nonspecific inhibitors of protein kinases. Trends Pharmacol. Sci. 1989, 10, 218-220. [CrossRef]

6. Hagiwara, H.; Choshi, T.; Fujimoto, H.; Sugino, E.; Hibino, S. A novel total synthesis of antibiotic carbazole alkaloid carbazomycin G. Tetrahedron 2000, 56, 5807-5811. [CrossRef]

7. Cuong, N.M.; Wilhelm, H.; Porzel, A.; Arnold, N.; Wessjohann, L. 1-O-Substituted derivatives of murrayafoline A and their antifungal properties. Prod. Res. 2008, 22, 1428-1432. [CrossRef]

8. Chakraborty, A.; Saha, C.; Podder, G.; Chowdhury, B.K.; Bhattacharyya, P. Carbazole alkaloid with antimicrobial activity from Clausena heptaphylla. Phytochemistry 1995, 38, 787-789. [CrossRef]

9. Clausen, J.D.; Kjellerup, L.; O’Hanlon, C.K.; Hansen, J.B.; Dalby-Brown, W.; Winther, A.-M.L. Elucidation of antimicrobial activity and mechanism of action by N-substituted carbazole derivatives. Bioorg. Med. Chem. Lett. 2017, 27, 4564-4570. [CrossRef]

10. Kaplancikli, Z.A.; Yurttaş, L.; Turan-Zitouni, G.; Özdemir, A.; Özic, R.; Ulusoylar-Yildirim, Ş. Synthesis, antimicrobial activity and cytotoxicity of some new carbazole derivatives. J. Enzyme. Inhib. Med. Chem. 2012, 27, 868-874. [CrossRef]

11. Sharma, D.; Kumar, N.; Pathak, D. Synthesis, characterization and biological evaluation of some newer carbazole derivatives. J. Serb. Chem. Soc. 2014, 79, 125-132. [CrossRef]

12. Desai, N.C.; Dodiya, A.M.; Rajpara, K.M.; Rupala, Y.M. Synthesis and antimicrobial screening of 1,3,4-oxadiazole and clubbed thiophene derivatives. J. Saudi Chem. Soc. 2014, 18, 255-261. [CrossRef]

13. Wani, M.Y.; Ahmad, A.; Shiekh, R.A.; Al-Ghamdi, K.J.; Sobral, A.J. Imidazole clubbed 1,3,4-oxadiazole derivatives as potential antifungal agents. Bioorg. Med. Chem. 2015, 23, 4172-4180. [CrossRef] [PubMed]

14. Dewangan, D.; Nakhate, K.T.; Tripathi, D.K.; Kashyap, P.; Dhongde, H. Synthesis, Characterization and Screening for Analgesic and Anti-inflammatory activities of 2,5-disubstituted 1,3,4-oxadiazole derivatives. Antiinflamm. Antiallergy Agents Med. Chem. 2015, 14, 138-145. [CrossRef]

15. Singh, A.K.; Lohani, M.; Parthsarthy, R. Synthesis, characterization and anti-inflammatory activity of some 1,3,4-oxadiazole derivatives. Iran J. Pharm. Res. 2013, 12, 319-323.

16. Gan, X.; Hu, D.; Chen, Z.; Wang, Y.; Song, B. Synthesis and antiviral evaluation of novel 1,3,4-oxadiazole/thiadiazolechalcone conjugates. Bioorg. Med. Chem. Lett. 2017, 27, 4298-4301. [CrossRef]

17. Abdo, N.Y.M.; Kamel, M.M. Synthesis and anticancer evaluation of 1,3,4-oxadiazoles, 1,3,4-thiadiazoles, 1,2,4-triazoles and Mannich bases. Chem. Pharm. Bull. 2015, 63, 369-376. [CrossRef]

18. Schlecker, R.; Thieme, P.C. The synthesis of antihypertensive 3-(1,3,4-oxadiazol-2-yl)phenoxypropanolamines. Tetrahedron 1988, 44, 3289-3294. [CrossRef]

19. Tabatabai, S.A.; Barghi Lashkari, S.; Zarrindast, M.R.; Gholibeikian, M.; Shafiee, A. Design, synthesis and anticonvulsant activity of 2-(2-phenoxy)phenyl-1,3,4-oxadiazole derivatives. Iran J. Pharm. Res. 2013, 12, 105-111.

20. Shyma, P.C.; Kalluraya, B.; Peethambar, S.K.; Vijesh, A.M. Synthesis, characterization, antidiabetic and antioxidant activity of 1,3,4-oxadiazole derivatives bearing 6-methyl pyridine moiety. Der Pharma Chem. 2015, 7, 137-145.

21. Musmade, D.; Pattan, S.; Yalgatti, M. Oxadiazole a nucleus with versatile biological behavior. Int. J. Pharm. Chem. 2015, 5, 11-20.

22. Sengupta, P.; Mal, M.; Mandal, S.; Singh, J.; Maity, T.K. Evaluation of antibacterial and antifungal activity of some 1,3,4-oxadiazoles. Iran J. Pharm. Ther. 2008, 7, 165-167.

23. Udrea, A.; Puia, A.; Shaposhnikov, S.; Avram, S. Computational approaches of new perspectives in the treatment of depression during pregnancy. Farmacia 2018, 66, 680-687. [CrossRef]

24. Hacker, K.; Maas, R.; Kornhuber, J.; Fromm, M.F.; Zolk, O. Substrate dependent inhibition of the human organic cation transporter OCT2: A comparation of Metformin with experimental substrates. PLoS ONE 2015, 10, e0136451. [CrossRef] [PubMed]

25. Nuta, D.C.; Marutescu, L.; Missir, A.V.; Morusciag, L.; Chirita, C.; Curutiu, C.; Badiceanu, C.D.; Papacocea, M.T.; Limban, C. In vitro evaluation of the antimicrobial activity of $\mathrm{N}$-phenylcarbamothioylbenzamides against planktonic and adherent microbial cells. Rom. Biotechnol. Lett. 2016, 22, 13163-13168. 
26. Limban, C.; Missir, A.V.; Caproiu, M.T.; Grumezescu, A.M.; Chifiriuc, C.M.; Bleotu, C.; Marutescu, L.; Papacocea, M.T.; Nuta, D.C. Novel Hybrid Formulations Based on Thiourea Derivatives and Core@Shell Fe3O4@C-18 Nanostructures for the Development of Antifungal Strategies. Nanomaterials 2018, 8, 47. [CrossRef]

27. Limban, C.; Missir, A.V.; Chirita, I.C.; Nitulescu, G.M.; Caproiu, M.T.; Chifiriuc, M.C.; Ismail, A.M. Synthesis and antimicrobial properties of new 2-((4-ethylphenoxy)methyl)benzoylthioureas. Chem. Pap. 2011, 65, 60-69. [CrossRef]

28. Nuţă, C.D.; Chifiriuc, M.C.; Drăghici, C.; Limban, C.; Missir, A.V.; Moruşciag, L. Synthesis, characterization and antimicrobial activity evaluation of new agents from benzamides class. Farmacia 2013, 61, 966-974.

29. Veber, D.F.; Johnson, S.R.; Cheng, H.Y.; Smith, B.R.; Ward, K.W.; Kopple, K.D. Molecular properties that influence the oral bioavailability of drug candidates. J. Med. Chem. 2002, 45, 2615-2623. [CrossRef]

30. ExPASy: SIB Bioinformatics Resource Portal. Available online: https://www.expasy.org/ (accessed on 28 November 2019).

31. Cheng, F.; Li, W.; Zhou, Y.; Shen, J.; Wu, Z.; Liu, G.; Lee, P.W.; Tang, Y. AdmetSAR: A comprehensive source and free tool for evaluating chemical ADMET properties. J. Chem. Inf. Model 2012, 52, 3099-3105. [CrossRef]

Sample Availability: Samples of the compounds are available from the authors. 